\title{
Electrochemiluminescence of CdTe Quantum Dots and Sensitive Detection of Hemoglobin
}

\author{
Kui-Yu Yi $i^{1^{*}}$, Chun-Sheng Wei ${ }^{2}$ \\ ${ }^{1}$ Department of Forensic Chemistry, Criminal Investigation Police University of China, Shenyang \\ 110854, China \\ 2 Department of Narcotics Control, Criminal Investigation Police University of China, Shenyang \\ 110854, China \\ *E-mail: yikuiyu@163.com
}

doi: $10.20964 / 2017.04 .100$

Received: 17 January 2017 / Accepted: 27 February 2017 / Published: 12 March 2017

CdTe quantum dots were modified to the surface of glassy carbon electrode (GCE) using Nafion, and the electrochemiluminescence (ECL) behavior of CdTe quantum dots immobilized in Nafion was investigated. Compared with ECL of CdTe quantum dots on the bare GCE, the ECL intensity of CdTe quantum dots modified into the Nafion film was obviously enhanced. Moreover, the ECL behavior of CdTe quantum dots in Nafion films had significant size dependence. CdTe quantum dots-Nafion could generate strong ECL signals in the presence of tripropylamine as the co-reactant in the phosphate buffer solution (PBS) at pH 7.0. A new method for the detection of hemoglobin was established based on hemoglobin could efficiently quench the ECL intensity of CdTe quantum dots. The results showed that the detection signal $\lg \left[\left(\mathrm{I}_{0}-\mathrm{I}\right) / \mathrm{I}\right]$ and the logarithm of hemoglobin concentration $\operatorname{lgC}$ had a good linear relationship between $1.0 \times 10^{-9} \mathrm{~mol} / \mathrm{L}$ and $5.0 \times 10^{-6} \mathrm{~mol} / \mathrm{L}$. The detection limit was $2.6 \times 10^{-10}$ $\mathrm{mol} / \mathrm{L}$.

Keywords: CdTe quantum dots; ECL quenching; tripropylamine; hemoglobin

\section{FULL TEXT}

(C) 2017 The Authors. Published by ESG (www.electrochemsci.org). This article is an open access article distributed under the terms and conditions of the Creative Commons Attribution license (http://creativecommons.org/licenses/by/4.0/). 